\title{
Isolation, chemical characterization and biological activity of red clover (Trifolium pratense $\mathbf{L}$.) root saponins
}

\author{
WIES AW OLESTEK. MARIAN JURZYSTA
}

Department of Biochemistry and Physiology of Crop Plants.

Institute of Soil Science and Plant Cultivation, 24-100 Puławy. Poland

(Received: September 10. 1985. Accepted November 26, 1985)

\begin{abstract}
Crystalline saponins were isolated from red clover (Trifolium pratense L.) roots. They were a mixture of two glycosides showing no haemolytic or fungistatic activity. Acid hydrolysis of these saponins yielded soyasapogenols B, C, D, E and F and rhamnose. xylose, arabinose. glucose and glucuronic acid as sugar components. They were poorly or not soluble in water and well soluble in ethanol. Water suspensions of these saponins did not affect winter wheat seedling growth.
\end{abstract}

Key words: Trifolium pratense roots, saponins, isolation, biological activity

\section{INTRODUCTION}

Red clover (Trifolium pratense L.) is, next to alfalfa, the most common legume pasture crop in Poland. Both red clover and alfalfa give good yields of high protein pasture. Furthermore, both crops are regarded as good stands, highly improving soil structure and fertility by leaving large amounts of roots in the soil (Roszak 1966). It is well recognized that alfalfa stands leave twice as much root dry matter as do red clover stands (Bawolski 1972, Starzycki 1981). However, it is also well known that establishment of a following crop such as wheat or cotton is poorer after alfalfa in comparison with other legume, crops, including red clover (Mishustin and Naumova 1955, Leshem and Levin 1962). It is generally believed that this detrimental effect of alfalfa on other plants is closely connected with the occurrence of a high concentration of saponins in alfalfa 
roots (Mishustin and Naumova 1955, Shany et al. 1970). These saponins show a quite high phytotoxic potential (Oleszek and Jurzysta 1986) and may reduce germination and growth of the subsequent crop making in this way alfalfa stands poorer than red clover ones. However, for further understanding of this phenomenon it was necessary to get some details concerning the occurrence of saponins in red clover roots. We have been unable to find anything on this subject in world literature. The aim of this research is thus the isolation and characterization of saponins from red clover roots.

\section{MATERIAL AND METHODS}

ISOLATION OF SAPONINS

Red clover (Trifolium pratense L. cv. Hruszowska) roots were collected from two year old field grown plants. The roots were washed with running water, dried at room temperature and finely ground. This material $(3.5 \mathrm{~kg})$ was defatted with methylene chloride and then extracted three times with $96^{\circ} \%$ ethanol ( $3 \mathrm{dm}^{3}$ per $300 \mathrm{~g}$ ). The ethanol extracts were combined, evaporated in vacuo (CS fraction) and macerated with water. After making sure by TLC that it contained no saponins, the water fraction was discarded. The residue was further purified in a small column $(10 \mathrm{~cm} \times 6 \mathrm{~cm})$ filled with Kieselgel 60 (70-230 mesh ASTM). The column was first eluted with acetone until the eluate was colorless. Then the saponins were washed out with $96^{\circ}$, ethanol. The TLC patterns of each particular fraction obtained during purification are presented on Fig. 1. The ethanol solution was evaporated to dryness and the dry residue dissolved in a small volume of alcohol-water mixture and the saponines crystallized. Threefold crystalization furnished a white, crystalline saponin representing $0.21 \%$ of the dry matter of red clover roots. This saponin was poorly (or not) soluble in water, well soluble in alcohol and melted with decomposition at ca. $227 \mathrm{C}$.

ACID HYDROLYSIS

$450 \mathrm{~g}$ of crude saponins (CS) were dissolved in $3 \mathrm{dm}^{3}$ of $2 \mathrm{~N} \mathrm{H}_{2} \mathrm{SO}_{4}$ in $50 \%$ methanol and bioled for $4 \mathrm{~h}$. After cooling, two volumes of water were added and the obtained suspension filtered. The filtrate was discarded and the precipitate $(110 \mathrm{~g})$ washed with water, dried and extracted in a Soxhlet apparatus with chloroform for $24 \mathrm{~h}$. The chloroform fraction was evaporated yielding $12 \mathrm{~g}$ of dry residue (CA). 


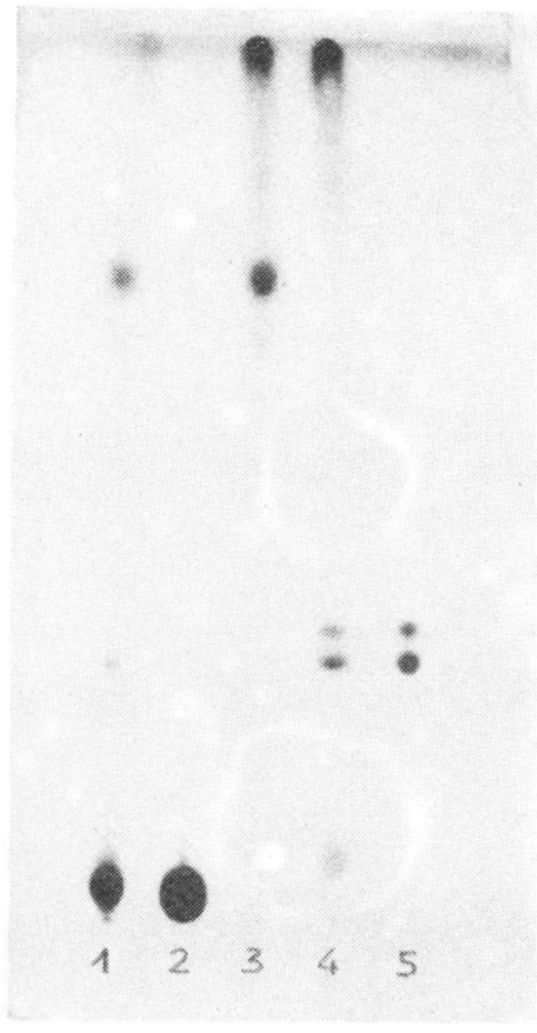

Fig. 1. The TLC of the main fractions obtained during purification of red clover root saponins. 1-ethanol extract of red clover roots; 2 - water fraction after maceration; 3 - acetone eluate; 4 - ethanol eluate; 5 - crystalline saponins 
For sugar analysis, $20 \mathrm{mg}$ of crystalline saponins were hydrolysed with $5 \mathrm{~cm}^{3} 2 \mathrm{~N} \mathrm{HCl}$ in $50 \%$ methanol for $8 \mathrm{~h}$, under reflux. After filtering of aglycones, the filtrate was evaporated in vacuo several times until $\mathrm{HCl}$ was completely removed and sugars chromatographed by TLC.

ISOLATION AND IDENTIFICATION OF AGLYCONES

The crude aglycones (CA) were chromatographed in a Kieselgel 60, $40 \mathrm{~cm} \times 3 \mathrm{~cm}$ column using $0.5-1.5 \%$ methanol in benzene, furnishing soyasapogenol B (512 mg) crystalline mp. 255-258 C (lit.) (Boar and Allen 1973, Jurzysta 1982) 257-259 C), MS m/z (rel. int.) 458 (2), 443 (1), 440 (2), 234 (100), 224 (10), 206 (10), 219 (34), 216 (10), 175 (26), 133 (11), 119 (15); soyasapogenol C (6 mg), crystalline, mp. 239-242 C (lit. (Boar and Allen 1973) 240-244 C), MS m/z 440 (1), 425 (2), 407 (1), 244 (11), 216 (100), 206 (9), 201 (12), 175 (13), 203 (4), 187 (4), 133 (6); soyasapogenol D $(64 \mathrm{mg})$, crystalline, mp. 297-298 C (lit. (Cainelli et al. 1958) 295-297 C), MS m/z 472 (16), 457 (3), 440 (4), 248 (22), 235 (23), 234 (9), 224 (10), 221 (10), 219 (7), 203 (100), 175 (28); soyasapogenol E (12.5 g), crystalline, mp. 248-249 C (lit. (Boar and Allen 1973) $250^{\circ} \mathrm{C}$ ), MS m/z 456 (1), 441 (1), 438 (1), 232 (100), 224 (14), 217 (21), 206 (19), 175 (39), 139 (19), 119 (30); soyasapogenol F (49 mg), crystalline, mp. 311-313 C (lit. (Jurzysta 1982) 316-318 C), MS m/z 458 (31), 443 (6), 440 (8), 425 (5), 234 (78), 224 (24), 221 (40), 220 (33), 206 (39), 205 (53), 203 (100), 157 (87). Melting points were measured with Buchi apparatus and MS with a LKB 9000 spectrometer.

THIN LAYER CHROMATOGRAPHY AND BIOASSAYS

TLC of glycosides and sugars, and bioassay tests were carried out according to the methods previously described (Oleszek and Jurzysta 1986).

\section{RESULTS AND DISCUSSION}

The thin layer chromatography of the ethanol extract of red clover roots showed two spots giving a positive reaction (pink-red colour) with a Liebermann-Burchard reagent. These two spots, possessing very close $\mathrm{R}_{f}$ values in the two developing systems used, were presumed to be triterpene glycosides. Further purification of crude ethanol extract by maceration with water and column chromatography made it possible to obtain a fraction pure enough that saponins could be crystallized readily. In this way, a crystal- 
Table 1

TLC characteristics of red clover root saponin

\begin{tabular}{|c|c|c|c|c|c|}
\hline \multirow{2}{*}{ Spot no. } & \multicolumn{2}{|c|}{$\mathrm{R}_{f}$ value } & \multicolumn{2}{c|}{$\begin{array}{c}\text { Colour after visualization with } \\
\text { Liebermann-Burchard reagent }\end{array}$} & \multirow{2}{*}{ Haemolysis } \\
\cline { 2 - 5 } & $\mathrm{S}_{1}$ & $\mathrm{~S}_{2}$ & in natural light & $\mathrm{UV}$ & \\
\hline 1 & 0.49 & 0.36 & pink-red & pink & - \\
2 & 0.46 & 0.33 & pink-red & pink & - \\
\hline
\end{tabular}

$S_{1}$-ethyl acetate-acetic acid-water $(7: 2: 2), S_{2}$-n-butanol-acetic acid-water $(4: 1: 1)$.

line compound was isolated with a yield of $0.21 \%$. This was a mixture of two not haemolytically active glycosides (Table 1), poorly soluble in water and well soluble in alcohol. Water suspensions of this compound at concentrations up to $10 \mathrm{mg} \cdot 100 \mathrm{~cm}^{3}$ did not affect $T$. viride growth. Acid hydrolysis furnished soyasapogenols B, C, D, E and F, and rhamnose, xylose, arabinose, glucose, and glucuronic acid as the sugar components.

Table 2

Effect of red clover root saponins on wheat seedling growth

\begin{tabular}{|l|c|c|}
\hline \multirow{2}{*}{$\begin{array}{c}\text { Saponin } \\
\text { concentration, ppm }\end{array}$} & Length of wheat seedlings, mm \\
\cline { 2 - 3 } 100 & tops & roots \\
\hline 500 & 80.0 & 83.0 \\
1000 & 84.3 & 89.0 \\
Control & 87.0 & 94.7 \\
\hline Tukay's s.d.d. $\mathrm{p}=95^{\circ} \%$ & 87.6 & 88.3 \\
\hline
\end{tabular}

There has yet been no report on the presence of saponins in red clover but there has been work done on the ladino clover (Trifolium repens) top saponins. The red clover root saponins isolated in our research appeared to be very similar to those obtained from ladino clover tops by Shibata and Myoga (1977) and by Myoga and Shibata (1977). In these studies, a crystalline compound was also isolated. which was a mixture of two glycosides giving, after acid hydrolysis, soyasapogenols B and C. These saponins did not haemolyse red blood cells and were not toxic to fish and rats (Myoga and Shibata 1975). Also Walter et al. (1955) isolated from ladino clover tops crystalline saponins that were a mixture of at least three different glycosides. Hydrolysis of this mixture yielded soyasapogenol B, C and a trace of a third compound whose structure was not established.

Comparing the results presented in this paper with data in earlier 
literature it can be concluded that red clover root saponins are the same or very similar to ladino clover top saponins both from the point of view of their chemical structure as well as of biological activity. They seem to be glycosides possessing soyasapogenol B as the sapogenin part. The additionally isolated soyasapogenols C, D and F are artifacts formed during acid hydrolysis as was earlier reported by Jurzysta (1982. 1984).

The phytotoxic potential of red clover root saponins was also researched. For that purpose, the influence of different concentrations of crystalline saponins on wheat germination and seedling growth was tested. The obtained results (Table 2) evidently proved that water suspensions of these saponins exhibit no inhibitory effect on wheat seedling growth. This lack of phytotoxic activity of red clover root saponins may indicate that red clover stands are much better for winter wheat establishment than alfalfa stands where alfalfa root saponins may have an influence on wheat seedling growth (Oleszek and Jurzysta 1986).

\section{REFERENCES}

Bawolski S., 1972. Dobór gatunków traw do mieszanek z lucerną, eparcetą i komonicą zwyczajną. Cz. 2. Wartość nawozowa resztek pożniwnych i wpływ następczy mieszanek. Pam. Puł. 51: 221-231.

Boar T. B.. Allen J.. 1973. R-Amyrin triterpenoids. Phytochemistry 12: 2571-2578.

Cainelli G.. Britt J. J.. Agrigoni D.. Jeger O.. 1958. Zur Kenntnis der Triterpene. 196 Mitt. Zur Konstitution der Soyasapogenole A, B, C und D. Helv. Chim. Acta 41: 2053-2058.

Jurzysta M.. 1982. Badania nad saponinami krajowych populacji lucerny mieszańcowej (Medicago media Pers.). Wyd. IUNG R (170).

Jurzysta M., 1984. Transformation of soyasapogenol B into soyasapogenols C. D and F under acidic conditions. Proc. Int. Symp. Chem. Nat. Prod. p. 127.

Leshem Y., Levin I.. 1962. The effect of growing alfalfa on subsequent cotton plant development and on nitrate formation in peat soil. Plant and Soil 50: 323-327.

Mishustin E. H., Naumova A. N.. 1955. Vydeleniye toksicheskikh vieshchestv lucernoy i vliyaniye ikh na khlopchatnik i mikrofloru poshvy. Zzv. Akad. Nauk SSSR 6: 3-9.

Myoga K., Shibata F., 1975. Biological activities of ladino clover saponins. Jap. J. Zoot. Sci. 46: 42-44.

Myoga K., Shibata F., 1977. Ladino clover saponin and the gas chromatographic assay method. J. Jap. Grassl. Sci. 23: 67-72.

Oleszek W., Jurzysta M.. 1986. Isolation. chemical characterization and biological activity of alfalfa (Medicago media Pers.) root saponins. Acta Soc. Bot. Pol. 55 (in press).

Roszak W., 1966. Badania wpływu roślin wieloletnich na produkcyiność gleby na podstawie ich działania na niektóre elementy jej żyzności oraz plony roślin następczych. Cz. 3 . Wpływ roślin wieloletnich na niektóre właściwości fizyczne i chemiczne gleby. Rocz. Nauk Roln. 91-A-4: 683-694.

Shany S., Birk Y., Gestetner B., Bondi A., 1970. Preparation, characterization and some properties of saponins from lucerne tops and roots. J. Sci. Food Agric. 21: 131-134.

Shibata F., Myoga K., 1977. Ladino clover saponin: Its chemical characteristics related to densitometric assay method. J. Jap. Grassl. Sci. 23: 60-66. 
Starzycki S., 1981. Koniczyny. PWRiL, Warszawa.

Walter E. D., Bickoff E. M., Thompson C. R., Robinson C. H., Djerassi C., 1955. Saponin from ladino clover (Trifolium repens). J. Amer. Chem. Soc. 77: 4936-4937.

Wyodrębnianie, charakterystyka chemiczna i aktywność biologiczna saponin korzeni koniczyny czerwonej (Trifolium pratense L.)

\section{Streszczenie}

Z korzeni koniczyny czerwonej (Trifolium pratense L.) wyodrębniono saponiny w stanie krystalicznym. Były one mieszaniną dwóch glikozydów o zbliżonych wartościach $\mathrm{R}_{f}$, które nie hemolizowały czerwonych ciałek krwi i nie hamowaly wzrostu grzyba Trichoderma viride. W wyniku hydrolizy kwasowej tych saponin otrzymano sojasapogenole B, C. D. E i F a w części cukrowej stwierdzono obecność ramnozy, ksylozy, arabinozy, glukozy i kwasu glukuronowego. Saponiny te były trudno rozpuszczalne w wodzie natomiast łatwo rozpuszczały się w alkoholu etylowym. Ich zawiesiny wodne nie miały wpływu na wzrost siewek pszenicy ozimej. 